\title{
PENGARUH KUALITAS SDM, KOMITMEN ORGANISASI, PEMANFAATAN TEKNOLOGI INFORMASI PADA EFEKTIVITAS PENERAPAN SAP BERBASIS AKRUAL
}

\author{
Kadek Agus Yogi Arta ${ }^{1}$ \\ I Ketut Yadnyana ${ }^{2}$ \\ ${ }^{1,2}$ Fakultas Ekonomi dan Bisnis Universitas Udayana, Bali, Indonesia \\ E-mail: agusyogiarta534@gmail.com
}

\begin{abstract}
Effect of Quality of Human Resources, Organizational Commitment, Use of Information Technology on the Effectiveness of Accrual-Based SAP Implementation. Based on knowing the influence of the quality of human resources, organizational commitment, and the application of information technology on the effectiveness of applying accrual-based government accounting standards to SKPD Karangasem Regency. As many as 134 civil servants in the financial section are the population as well as samples from this study because the sampling technique used is saturated samples. multiple linear regression is the analysis techniques that used in this study, and the results show that the quality of HR, organizational commitment and the application of information technology have a positive influence on the effectiveness of accrual-based SAP implementation in the SKPD of Karangasem Regency.
\end{abstract}

Keywords: quality of human resources; organizational commitment; utilization of information technology; effectiveness of the application of accrual-based government accounting standards

\begin{abstract}
Abstrak: Pengaruh Kualitas SDM, Komitmen Organisasi, Pemanfaatan Teknologi Informasi pada Efektivitas Penerapan SAP Berbasis Akrual. Dengan berdasarkan untuk mengetahui pengaruh dari kualitas SDM, komitmen organisasi, serta penerapan teknologi informasi pada efektivitas penerapan standar akuntansi pemerintah berbasis akrual pada SKPD Kabupaten Karangasem. Pegawai negeri sipil pada bagian keuangan sebanyak 134 orang merupakan populasi sekaligus sampel dari penelitian ini karena teknik pengambilan sampel yang digunakan adalah sampel jenuh. Dengan teknik analisis data regresi linier berganda, didapatkan hasil bahwa kualitas SDM, komitmen organisasi serta penerapan teknologi informasi memiliki pengaruh yang positif pada efektivitas penerapan SAP berbasis akrual pada SKPD Kabupaten Karangasem.
\end{abstract}

Kata kunci: kualitas sumber daya manusia; komitmen organisasi; pemanfaatan teknologi informasi; efektivitas penerapan standar akuntansi pemerintah berbasis akrual 


\section{PENDAHULUAN}

Pemerintah terus berusaha memberi perubahan kea rah yang lebih baik untuk pengelolaan keuangan pemerintah Negara. Hal yang terutama dikembangkan oleh pemerintah mengenai pengelolaan keuangan adalah meningkatkan transparansi pengelolaan keuangan Negara dan juga meningkatkan akuntabilitas pengelolaan keuangan Negara.

Dalam melakukan penyusunan laporan keuangan terutama di pemerintahan terdapat standar yang harus diikuti oleh anggota organisasi yaitu Standar Akuntansi Pemerintah atau SAP. Bukan hanya pemerintah ada berada di daerah, SAP ini juga berlaku bagi pemerintah pusat. Dengan adanya SAP diharapkan laporan keuangan yang dihasilkan oleh pemerintahan memiliki kualitas yang baik dan dapat dipercaya. Penting bagi sebuah laporan keuangan untuk memiliki kualitas yang baik dan dapat dipercaya karena dari informasi yang dihasilkan oleh laporan keuangan tersebut kemudian akan dijadikan dasar dalam pengambilan keputusan yang berdampak pada masyarakat.

Indonesia adalah yang lebih dahulu menerapkan SAP berbasis akrual di ASEAN, hal ini diharapkan dapat menimbulkan trust, khususnya para investor bahwa Indonesia akan memiliki sebuah laporan yang menggambarkan hak dan kewajiban dengan tepat.

Pada tahun 2014 Karangasem, Bangli dan Klungkung masih berkutat dengan opini WDP atas audit LKPD. Berdasarkan artikel yang berjudul BPK mengeluarkan rapor atau audit LKPD Kabupaten/Kota se-Bali pada tanggal 2 Juni 2015 dikatakan bahwa kabupaten Karangasem menjadi salah satu kabupaten yang gagal naik kelas karena masih mendapatkan gelar Wajar Dengan Pengecualian (WDP) dari hasil audit Laporan Keuangan Pemerintah Daerah (LKPD). Delapan daerah lainnya meraih predikat tertinggi Wajar Tanpa Pengecualian (WTP) yaitu: Buleleng, Tabanan, Jembrana, Denpasar, Badung, Gianyar, dan Klungkung.

BPK melakukan peneriksaan pada SPI selama periode 2010-2016 dan menemukan beberapa kelemahan pada SPI dari laporan keuangan Kabupaten Karangasem yaitu pengelolaan persediaan pada Tiga SKPD di Pemerintah Kabupaten Karangasem Kurang Tertib, aplikasi SIM-PBB (Sistem Informasi Manajemen Pajak Bumi dan Bangunan) belum sepenuhnya mendukung penyusunan laporan keuangan berbasis akrual, Penerapan perlakuan akuntansi asset tetap atas beberapa barang milik daerah belum tepat, Laporan akuntabilitas kinerja instansi pemerintah kabupaten karangasem tahun 2016, dikatakan bahwa belum ada PNS yang telah lulus penjenjangan pendidikan S1, sedangkan pemerintah menargetkan jumlah PNS yang lulus pendidikan S1 minimal ialah 5 orang disetiap dinas. Dimana hal tersebut dapat menunjang peningkatan sumber daya aparatur pemerintahan. Permasalahan yang dijelaskan di atas dalam penelitian ini menghasilkan beberapa variabel yang memengaruhi dari penerapan SAP Akrual, di antaranya yaitu kompetensi sumber daya manusia, komitmen organisasi dan pemanfaatan teknologi informasi.

Meminimalisir kelemahan dalam penyusunan laporan keuangan sangat didukung adanya sumber daya manusia yang profesional dan dapat memahami SAP berbasis akrual. SAP berbasis akrual dapat diterapkan dengan baik apabila kualitas aparatur pemerintah yang terlibat dalam penyusunan laporan keuangan sesuai dengan aturan yang diterapkan. Standar akuntansi pemerintahan berpengaruh dari faktor SDM, komitmen organisasi, dan pemanfaatan teknologi informasi akan memiliki dampak pada keberhasilan penyusunan laporan keuangan (Davis, 2010).

Akuntansi berbasis akrual seharusnya segera diwajibkan paling lambat tahun 2008, namun kesulitan dalam mengubah kebiasaan dari penggunaan basis kas dan lebih kompleksnya basis akrual, maka pemerintah memperpanjang masa transisi untuk penerapan basis akrual sampai tahun 2015 . Komitmen yang kuat dari seorang pemimpin merupakan salah satu hal yang penting agar pemimpin dapat memotivasi semua aggota 
Tabel 1.

Perkembangan Opini BPK RI terhadap LKPD Provinsi/Kabupaten/Kota di Provinsi Bali Tahun 2010/2016

\begin{tabular}{|c|c|c|c|c|c|c|c|c|}
\hline \multirow{2}{*}{ No. } & \multirow{2}{*}{ LKPD } & \multicolumn{7}{|c|}{ Opini BPK } \\
\hline & & 2010 & 2011 & 2012 & 2013 & 2014 & 2015 & 2016 \\
\hline 1 & Kota Denpasar & WDP & WDP & WDP & WTP & WTP & WTP & WTP \\
\hline 2 & $\begin{array}{l}\text { Kabupaten } \\
\text { Badung }\end{array}$ & WDP & WTP & WTP & TW & WTP & WTP & WTP \\
\hline 3 & $\begin{array}{l}\text { Kabupaten } \\
\text { Gianyar }\end{array}$ & WDP & WDP & WDP & WDP & WTP & WTP & WTP \\
\hline 4 & Kabupaten Bangli & WDP & WDP & WDP & TMP & WDP & WDP & WTP \\
\hline 5 & $\begin{array}{l}\text { Kabupaten } \\
\text { Klungkung }\end{array}$ & WDP & WDP & WDP & WDP & WDP & WTP & WTP \\
\hline 6 & $\begin{array}{l}\text { Kabupaten } \\
\text { Karangasem }\end{array}$ & TMP & WDP & WDP & WDP & WDP & WDP & WTP \\
\hline 7 & $\begin{array}{l}\text { Kabupaten } \\
\text { Buleleng }\end{array}$ & TMP & WDP & WDP & WDP & WTP & WTP & WTP \\
\hline 8 & $\begin{array}{l}\text { Kabupaten } \\
\text { Tabanan }\end{array}$ & WDP & WDP & TMP & WDP & WTP & WTP & WTP \\
\hline 9 & $\begin{array}{l}\text { Kabupaten } \\
\text { Jembrana }\end{array}$ & TW & WDP & WDP & WDP & WTP & WTP & WTP \\
\hline 10 & Provinsi Bali & WDP & WDP & WDP & WTP & WTP & WTP & WTP \\
\hline
\end{tabular}

dalam suatu organisasi guna terciptanya tujuan organisasi tersebut. Komitmen merupakan kesanggupanuntuk bertanggung jawab terhadap hal-halyang dipercayakan kepada seseorang (Simanjuntak, 2005).

Ritonga (2010) berpendapat dengan menggunakan SAP dengan basis akrual maka segala transaksi yang dilakukan akan dicatat pada saat itu juga.

Standar akuntansi pemerintah berbasis akrual memiliki berbagai keunggulan dibandingkan dengan standar akuntansi pemerintah berbasis kas, diantaranya mengidentifikasi biaya, memungkinkan pengendalian biaya dan pengukuran efisiensi, menjamin akuntanbilitas penggunaan sumber daya, dan berfokus pada dampak jangka panjang dari keputusan (Stefanescu, 2011)

Akuntansi pemerintah berbasis akrual juga memungkinkan pemerintah untuk mengidentifikasi kesempatan dalam menggunakan sumber daya masa depan dan mewujudkan pengeloaan yang baik atas sumber daya tersebut (Grandis, 2012).
Dalam hal ini maka dapat disimpulkan bahwa pencatatan menggunakan basis akrual lebih mencerminkan keadaan suatu organisasi dan lebih dapat mengukur kinerja organisasi (Adriana, 2008).

Efektivitas Penerapan Standar Akuntansi Pemerintahan Anthony \& Govindrajan (2007;174) keputusan yang dihasilkan oleh pimpinan organisasi memiliki hubungan dengan efektivitas dari kinerja organisasi yang dipimpinnya. Dengan menghasilkan sesuatu yang sesuai dengan tujuan yang ingin dicapai maka sistem yang digunakan oleh organisasi tersebut dapat dikatakan efektif. Begitu juga dengan pemerinthan, ketika tujuan yang di tetapkan oleh pemerintah tercapai maka penerapan SAP dapat dikategorikan sebagai sistem yang efektif yang digunakan oleh pemerintah. Sebelum menerapkan SAP, pemerintah harus terlebih dahulu menetapkan tujuan yang ingin dicapai. Ketika pemerintah telah menetapkan tujuan yang ingin dicapai yaitu pemerintah bertujuan untuk meningkatkaan kualitas 
laporan keuangan pusat maupun daerah, maka dapat diterapkan SAP tersebut dan melihat seberapa efektif SAP dapat mewujudkan tujuan pemerintah.

Sumber daya manusia adalah penggerak roda organisasi itu sendiri serta merupakanpenyangga utama dalam suatu organisasi untuk mewujudkan visi dan misi serta tujuan dari organisasi tersebut. Selain itu, sumber daya manusia merupakan faktor terpenting dalam organisasi pemerintahan untuk menjalankan fungsi-fungsinya di dalam organisasi itu sendiri. Dikarenakan SDM merupakan haarta penting bagi suatu organisasi, organisasi tersebut harus memperlakukan SDM yang dimiliki dengan baik dan sebisa mungkin mengembangkan SDM tersebut yang kemudian akan berdampak pada kemajuan dari organisasi tersebut.

Merriam Webster dalam Zangaro (2007), menyimpulkan definisi komitmen adalah sebuat perilaku yang menjanjikan untuk memenuhi kewajiban kepada seseorang atau sesuatu di masa yang akan datang. Ketika individu memiliki keinginan yang sangat kuat untuk bertahan pada suatu organisasi hal tersebut disebut dengan komitmen organisasi. Individu yang memiliki komitmen organisasi yang tinggi akan berusaha untuk membawa kemajuan bagi organisasi tempatnya bekerja dan berfokus pada tujuan organisasinya yang salah satunya dengan mendukung penerapan SAP berbasis akrual (Luthans, 2006;249).

Pemanfaatan teknologi yang sudah sangat maju di jaman sekarang sangat berdampak untuk keberhasilan penerapan SAP dengan basis akrual. Teknologi ini sangat berguna untuk melakukan olah data agar dapat menghasilkan informasi yang berkualitas (Widyastuti, 2015). Yang dimaksud dengan pemanfaatan TI yaitu adanya sarana untuk melakukan olah data, adanya sarana untuk mengolah informasi, pekerjaan dilakukan secara sistematis dengan menggunakan elektronik, pelayanan kepada masyarakat lebih efisien dan efektif dengan memanfaatkan kemutakhiran teknologi yang ada. Dan pemanfaatan TI ini diharapkan dapat dirasakan efektivitas dan efisiensinya oleh seluruh lapisan masyarat (Hamzah, 2009).

\section{METODE PENELITIAN}

Lokasi penelitian ini dilakukan di Pemerintah Daerah Kabupaten Karangasem yang mencangkup seluruh unit SKPD (Satuan Kerja Perangkat Daerah).

Objek yang digunakan dalam penelitian adalah pengaruh kualitas sumber daya manusia, komitmen organisasi, pemanfaatan teknologi informasi, dan penerapan standar akuntansi pemerintah berbasis akrual.

Peneliti memilih tiga variabel independen yaitu yang pertama kualitas SDM yaitu sebagai X1, yang kedua adalah komitmen organisasi sebagai X2, dan pemanfaatan teknologi informasi sebagai X3 . Variabel terikat atau dependent (Y) adalah variabel yang dipengaruhi oleh variabel bebas (Sugiyono, 2018;59). Peneliti memilih efektivitas penerapan SAP sebagai variabel bebas atau dependent.

Efektivitas Penerapan standar
akuntansi pemerintah berbasis akrual adalah persepsi responden tentang kesiapan instansi untuk merubah metode pencatatan transaksinya yang awalnya menggunakan SAP dengan basis kas dan berubah menjadi menggunakan SAP dengan basis akrual dan juga proses hingga tujuan tersebut tercapai, dilihat juga bagaimana instansi memberikan kontribusi selama proses perubahan tersebut. Indikator untuk mengukur penerapan standar akuntansi pemerintah berbasis akrual adalah (1) pengakuan terhadap pendapatan, beban, aset, uang, dan ekuitas. (2) pengolahan data keuangan sesuai dengan PP No. 71 (3) keadaan posisi dari SDM, tugas dan ekuitas pemerintah, (4) pelatihan tetntang standar akuntansi berbasis akrual, (5) penyusunan laporan keuangan sesuai SAP dengan basis tanpa bantuan dari eksternal, (6) penyusunan laporan keuangan sesuai SAP dengan basis akrual dengan kerjasama pihak luar.

Kualitas sumber daya manusia adalah kualitas yang berhubungan dengan pengetahuan, keterampilan, kemampuan, dan karakteristik yang memengaruhi secara langsung terhadap kinerjanya dalam penerapan 
sistem akuntansi akrual. Indikator untuk mengukur kualitas sumber daya manusia adalah (1) penempatan pegawai, (2) pegawai kurang memahami pekerjaannya, (3) pegawai tidak siap melakukan perubahan penyusunan laporan keuangan, (4) pegawai tidak mengerti isi dari PP No. 71 tahun 2010, (5) tidak memiliki SDM yang mampu dalam menyusun laporan keuangan instansi, (6) memahami standar akuntansi pemerintah berbasis akrual, (7) pernah mengikuti pendidikan dan pelatihan mengenai penerapan PP No. 71 tahun 2010.

Ketika individu memiliki keinginan yang sangat kuat untuk bertahan pada suatu organisasi hal tersebut disebut dengan komitmen organisasi. Individu yang memiliki komitmen organisasi yang tinggi akan berusaha untuk membawa kemajuan bagi organisasi tempatnya bekerja dan berfokus pada tujuan organisasinya yang salah satunya dengan mendukung penerapan SAP berbasis akrual. Indikator untuk mengukur komitmen organisasi adalah (1) kesiapan komitmen yang tinggi,(2)komitmen mensosialisasikan PP. No. 71 tahun 2010, (3) komitmen menyelesaikan penyusunan leporan keuangan tepat waktu, (4) komitmen menyelesaikan laporan keuangan sesuai dengan standar akuntansi pemerintah yang berlaku.

Pemanfaatan teknologi informasi adalah ketika terdapat teknologi yang dapat digunakan digunakan dengan mudah untuk menghasilkan informasi yang dibutuhkaan. Teknologi tersebut juga sudah terintegrasi sehingga memudahkan pengguna dan dapat digunakan untuk mengolah data dan dapat menghasilkan informasi yang akurat dan dapat digunkan untuk mendukung penerapan SAP. Indikator untuk mengukur pemanfaatan teknologi informasi adalah (1) sistem manajemen informasi, (2) sistem sistem dalam perangkat lunak SAP, (3) pelatihan peningkatan kualitas pemangku pelaksana sistem perangkat lunak SAP, (4) pendamping dalam operasional pelaksanaan sistem perangkat lunak SAP.

Jenis data yang digunakan dalam penelitian ini yaitu data kuantitatif. Data kuantitatif merupakan data penelitian berupa angka-angka dan analisis menggunakan statistik (Sugiyono, 2018). Data yang dimaksud meliputi data kuesioner mengenai kualitas sumber daya manusia, komitmen organisasi, pemanfaatan teknologi informasi, dan Efektivitas penerapan standar akuntansi pemerintah berbasis akrual.

Data primer adalah sumber data yang langsung memberikan data kepada pengumpul data, dan tidak melalui perantara (Sugiyono, 2018). Data primer dalam penelitian ini adalah data yang diperoleh langsung dari Keuangan Pejabat Penatausahaan Satuan Kerja Perangkat Daerah (PPK SKPD) yang ada di Kabupaten Karangasem dengan menggunakan daftar pertanyaan dalam bentuk kuesioner.

Data Sekunder adalah data yang tidak langsung memberikan data kepada pengumpul data, seperti melalui orang lain atau lewat dokumen (Sugiyono, 2018). Data sekunder dalam penelitian ini berupa struktur organisasi dan data mengenai jumlah satuan kerja di setiap wilayah yang menjadi objek penelitian yang diperoleh melalui web masing-masing wilayah objek.

Populasi menurut Sugiyono yaitu sekumpulan objek atau subjek yang memiliki suatu karakteristik tertentu yang tidak dimiliki oleh objek atau subjek yang lain yang dipilih oleh peneliti untuk dipelajari dan dianalisis lebih lanjut (Sugiyono, 2018). Populasi yang dipilih oleh peneliti adalah PNS bagian staf keuangan di Kabupaten Karangasem dengan jumlah keseluruhan 134 orang.

Sampel adalah bagian dari jumlah dan karakteristik yang dimiliki oleh populasi tersebut (Sugiyono, 2018). Teknik penelitian ini menggunakan sampel jenuh yang mencangkup pegawai yang melaksanakan tugas dan fungsi tata usaha keuangan pada SKPD yaitu penjabat penatausahaan keuangan satuan kerja perangkat daerah (PPK-SKPD), jadi jumlah sampel dalam penelitian ini adalah 134.

Pada penelitian ini menggunakan metode kuesioner. Kuesioner adalah teknik pengumpulan data yang dilakukan dengan cara memberikan seperangkat pertanyaan atau pernyataan tertulis kepada responden untuk 
Tabel 2.

Daftar Nama beserta jumlah Pegawai di bagian keuangan pada SKPD di Kabupaten Karangasem

\begin{tabular}{clc}
\hline No & \multicolumn{1}{c}{ Nama SKPD } & Jumlah \\
\hline 1 & Dinas Pendidikan, Pemuda, dan Olah Raga & 8 \\
2 & Dinas Kesehatan & 7 \\
3 & Dinas Pekerjaan Umum dan Penataan Ruang & 6 \\
4 & Dinas Perumahan dan Kawasan Pemukiman & 12 \\
5 & Dinas Sosial, Tenaga Kerja, dan Transmigrasi & 7 \\
6 & Dinas Ketenagakerjaan & 4 \\
7 & Dinas Pemadam Kebakaran & 5 \\
8 & Dinas Pemberdayaan Perempuan dan Perlindungan Anak & 2 \\
9 & Dinas Pengendalian Penduduk dan Keluarga Berencana & 3 \\
10 & Dinas Ketahanan Pangan & 6 \\
11 & Dinas Lingkungan Hidup & 9 \\
12 & Dinas Kependudukan dan Catatan Sipil & 5 \\
13 & Dinas Perberdayaan Masyarakat dan Desa & 4 \\
14 & Dinas Perhubungan & 7 \\
15 & DinasKomunikasi, dan Informatika & 2 \\
16 & Dinas Koperasi, Usaha Mikro, Kecil dan Menengah & 4 \\
17 & Dinas Kebudayaan & 8 \\
18 & Dinas Penanaman Modal dan Pelayanan Terpadu Satu Pintu & 6 \\
19 & Dinas Perpustakaan dan Kearsipan & 3 \\
20 & Dinas Pariwisata & 8 \\
21 & Dinas Perikanan & 6 \\
22 & Dinas Pertanian & 4 \\
23 & Dinas Perindustrian dan Perdagangan & 4 \\
24 & Satuan Polisi Pamong Praja & 4 \\
\hline & \multicolumn{2}{c}{ Total } \\
\hline
\end{tabular}

Sumber: data diolah 2016

dijawabnya (Sugiyono, 2018).

akrual.

Yang pertama adalah dengan observasi.

Kegiatan observasi dilakukan dengan cara pengamatan langsung ke lokasi di SKPD Kabupaten Karangasem dan mencatat hal-hal yang relevan terhadap objek yang diteliti.

Kuesioner merupakan teknik pengumpulan data yang dilakukan dengan cara seperangkat pertanyaan atau pernyataan tertulis kepda responden untuk dijawabnya (Sugiyono, 2018). Cara pengumpulan data dengan menggunakan daftar pertanyaan yang disebarkan kepada responden yang berkaitan dengan variabel kualitas SDM, komitmen organisasi, pemanfaatan teknologi informasi, dan Efektivitas penerapan SAP dengan basis

Penelitian melakukan wawancara terlebih dahulu sebagai pendahuluan untuk mengetahui keadaan dari responden yang kemudian akan diteliti lebih lanjut dengan menggunakan analisis data. Dengan dilakukannya wawancara, peneliti dapat mengetahui lebih spesifik mengenai objek yang akan diteliti shingga memudahkan peneliti untuk menarik kesimpulan setelah dilakukannya analisis data (Sugiyono, 2018). Pengumpulan data dengan menggunakan metode wawancara dilaksanakan dengan melakukan tanya jawab secara langsung dengan pemimpin instansi terhadap masalah yang di teliti dalam penelitian ini. 
Tabel 3.

Karakteristik Responden

\begin{tabular}{lllrr}
\hline No. & Karakteristik & Klasifikasi & $\begin{array}{c}\text { Jumlah } \\
\text { (Orang) }\end{array}$ & $\begin{array}{c}\text { Persentase } \\
\text { (\%) }\end{array}$ \\
\hline 1 & Jenis kelamin & Laki-laki & 65 & 48 \\
& & Perempuan & 69 & 52 \\
\multirow{2}{*}{2} & Usia & Jumlah & 134 & 100 \\
& & 20-30 tahun & 15 & 11 \\
& & $31-40$ tahun & 60 & 45 \\
& & $>40$ tahun & 59 & 44 \\
3 & Jumlah & 134 & 100 \\
& Pendidikan & SMA & 52 & 39 \\
& Terakhir & D3 & 42 & 31 \\
& & S1 & 32 & 24 \\
& & S2 & 8 & 6 \\
& & S3 & 0 & 0 \\
4 & Masa kerja & Jumlah & 134 & 100 \\
& & $1-5$ tahun & 34 & 25 \\
& 6-10 tahun & 43 & 32 \\
& & $>10$ tahun & 57 & 43 \\
& & Jumlah & 134 & 100 \\
\hline
\end{tabular}

Tabel 4.

Hasil Statistik Deskriptif

\begin{tabular}{lccccc}
\hline \multicolumn{1}{c}{ Variabel } & N & Min & Maks & Mean & $\begin{array}{c}\text { Std. } \\
\text { Deviation }\end{array}$ \\
\hline Kualitas SDM (X1) & 134 & 10,00 & 34,00 & 24.40 & 5.211 \\
Komitmen Organisasi (X2) & 134 & 6,00 & 19,00 & 12.47 & 3.015 \\
Pemanfaatan Teknologi Informasi (X3) & 134 & 8,00 & 20,00 & 13.40 & 3.026 \\
Efektivitas SAP Berbasis Akrual (Y) & 134 & 10,00 & 29,00 & 19.78 & 4.256 \\
Valid N (listwise) & 134 & & & & \\
\hline Sumber: Data primer diolah, 2018 & & & & &
\end{tabular}

\section{HASIL DAN PEMBAHASAN}

Jumlah responden 134 orang maka disebarkan sebanyak 134 kuisioner. Tingkan pengembalian dari kuisioner adalah 100 persen atau seluruh kuisioner yang disebarkan kembali secara terisi dan utuh yaitu sebanyak 134 kuisioner. Dari 134 kuisioner yang dibagikan tidak ada kuisioner yang tidak dapat diolah sehingga seluruh kuisioner yang dikembalikan dapat digunakan untuk tahap analisis selanjutnya.

Penjabaran dari karakteristik responden dalam penelitian ini yaitu dari total 134 orang responden, 65 orang adalah berjenis kelamin laki-laki dan sisanya 69 orang berjenis kelamin perempuan. Responden yang berusia 20-30 tahun yaitu 15 orang, 31-40 tahun yaitu 60 orang dan diatas 40 tahun yaitu 59 orang. Responden pada penelitian ini yang merupakan lulusan SMA yaitu 52 orang, D3 yaitu 42 orang, S1 yaitu 32 orang, S2 yaitu 8 orang dan tidak ada yang S3. Responden yang memiliki masa kerja 1 tahun sampai 5 tahun adalah sebanyak 34 orang, responden dengan masa kerja 6 tahun sampai 10 tahun yaitu sebanyak 43 orang, responden dengan masa kerja diatas 10 tahun yaitu sebanyak 57 orang. Hasil dari uji statistik deskriptif menunjukan bahwa kualitas SDM sebagai X1 sejumlah 134 dengan nilai Min. yaitu 10,00 
Tabel 5.

Hasil Uji Reliabilitas

\begin{tabular}{clcc}
\hline No & \multicolumn{1}{c}{ Variable } & Cronbach Alpha & Keterangan \\
\hline 1 & Kualitas SDM (X1) & 0,795 & Reliable \\
2 & Komitmen Organisasi (X2) & 0,748 & Reliable \\
3 & Pemanfaatan Teknologi Informasi (X3) & 0,747 & Reliable \\
4 & Efektivitas SAP Berbasis Akrual (Y) & 0,764 & Reliable \\
\hline Sumber : Data diolah, 2018
\end{tabular}

Tabel 6.

Hasil Uji Normalitas

\begin{tabular}{cc}
\hline Kolmogorov-Smirnov & Unstandardized Residual \\
\hline $\mathrm{N}$ & 134 \\
Asymp.Sig.(2-tailed) & 0,662 \\
\hline Sumber : Data diolah, 2018 &
\end{tabular}

dan nilai Maks. yaitu 34,00. Rata-rata dari variabel kualitas SDM adalah 24,40 dimana nilai ini lebih mengarah ke angka maksimum yaitu 34,00 yang berari kualitas SDM pada sampel penelitian ini terbilang tinggi.

Hasil dari uji statistik deskriptif menunjukan bahwa komitmen organisasi sebagai X2 sejumlah 134 memiliki nilai minimum yaitu 6,00 dan nilai maksimum yaitu 19,00. Rata-rata dari variabel komitmen organisasi adalah 12,47 dimana nilai ini lebih mengarah ke angka maksimum yaitu 19,00 yang berari komitmen organisasi pada sampel penelitian ini terbilang tinggi.

Hasil dari uji statistik deskriptif menunjukan bahwa pemanfaatan teknologi informasi sebagai X3 sejumlah 134 memiliki nilai minimum yaitu 8,00 dan nilai maksimum yaitu 20,00. Rata-rata dari variabel pemanfaatan teknologi informasi adalah 13,40 dimana nilai ini lebih mengarah ke angka maksimum yaitu 20,00 yang berari pemanfaatan teknologi informasi pada sampel penelitian ini terbilang tinggi.

Hasil dari uji statistik deskriptif menunjukan bahwa efektivitas SAP berbasis akrual sebagai Y sejumlah 134 bernilai Min. yaitu 10,00 dan nilai Maks 29,00. Rata-rata dari variabel efektivitas SAP berbasis akrual adalah 19,78 dimana nilai ini lebih mengarah ke angka maksimum yaitu 29,00 yang berari efektivitas SAP berbasis akrual pada sampel penelitian ini terbilang tinggi.

Uji validitas ditujukan untuk mengukur seberapa nyata suatu pengujian atau instrumen. valid berarti variabel tersebut dapat digunakan untuk mengukur apa yang seharusnya diukur. Validitas dalam penelitian dijelaskan sebagai satuan acuan ketepatan alat ukur penelitian tentang inti atau arti sebenarrnya yang diukur (Husein, 2004). Untuk melihat apakah pernyataan dalam kuisioner yang digunakan sudah tepat untuk digunakan atau tidak dapat dilihat dari uji validitas diamana pernyataanpernyataan tersebut memiliki nilai diatas 0,30 . Dengan nilai diatas 0,30 maka dapat dinyataan bahwa pernyataan yang digunakan dalam penelitian ini valid (Sugiyono, 2018).

Berdasarkan hasil uji validitas didapatkan hasil bahwa seluruh pernyataan di dalam kuisioner yang digunakan dalam penelitian ini adalah valid karena memiliki nilai yang melebihi 0,30 ,

Setelah melakukan uji reliabilitas didapatkan hasil bahwa seluruh instrumen penelitian yaitu memiliki nilai Cronbach's Alpha melebihi 0,70 sehingga bisa digunakan untuk penelitian ini.

Model yang digunakan dalam penelitian ini telah memnuhi syarat dari uji normalitas dan memiliki distribusi normal karena memiliki nilai sig. yang melebihi 0,05 yaitu 0,662 .

Untuk mengetahui apakah terdapat korelasi antar variabel bebas pada model regresi yang digunakan memiliki korelasi atau tidak perlu dilakukan uji multikolinearitas. Agar model regresi dapat digunakan, model regresi harus memenuhi syarat yaitu 
Tabel 7.

Hasil Uji Multikolinearitas

\begin{tabular}{lcc}
\hline \multicolumn{1}{c}{ Variable } & Tolerance & VIF \\
\hline Kualitas SDM (X1) & 0,970 & 1,031 \\
Komitmen Organisasi (X2) & 0,986 & 1,014 \\
Pemanfaatan Teknologi Informasi (X3) & 0,964 & 1,038 \\
\hline Sumber: Data diolah, 2018
\end{tabular}

Tabel 8.

Hasil Uji Heteroskedastisitas

\begin{tabular}{lcc}
\hline \multicolumn{1}{c}{ Variabel } & Sig. & Keterangan \\
\hline Kualitas Sumber Daya Manusia (X1) & 0.273 & Bebas heteroskedastisitas \\
Komitmen Organisasi (X2) & 0.868 & Bebas heteroskedastisitas \\
Pemanfaatan Teknologi Informasi (X3) & 0.245 & Bebas heteroskedastisitas \\
\hline Sumber : Data diolah, 2018 & &
\end{tabular}

terbebas dari masalah multikolinearitas. Uji multikolinearitas bertujuan untuk mengetahui apakah antar variabel bebas dalam persamaan regresi tidak saling berkolerasi (Ghozali, 2016;104). Pada uji multikolinearitas nilai tolerance harus lebih besar dari $10 \%$ atau nilai VIF harus lebih besar dari 10 agar model regresi yang digunakan dalam penelitian ini terbebas dari masalah multikolinearitas.

Model yang digunakan dalam penelitian ini telah memenuhi syarat dari uji multikolinearitas dan terbebas dari masalah multikoliearitas. Hal tersebut dapat dilihat dari dari nilai tolerance yang lebih besar dari 10\% dan nilai VIF lebih besar dari 10.

Untuk mengetahui apakah terdapat masalah heteroskedastisitas pada model regresi yang digunakan dalam penelitian ini maka harus dilakukan uji heteroskedastisitas. Agar model regresi dapat digunakan, model regresi harus memenuhi syarat yaitu terbebas dari masalah heteroskedastisitas. Pada uji heteroskedastisitas nilai dari t hitung harus lebih rendah dari t tabel serta nilai signifikan $\mathrm{t}$ hitung harus melebihi 0,05 agar terbebas dari masalah heteroskedastisitas.

Model yang digunakan dalam penelitian ini telah memenuhi syarat dari uji heteroskedastisitas dan terbebas dari masalah heteroskedastisitas karena memiliki nilai sig yang melebihi 0,05 .

Pengujian selanjutnya adalah analisis regresi linier berganda yang dilakukan untuk mengetahui pengaruh dari variabel-variabel bebas pada variabel terikat yang digunakan dalam penelitian ini. Pengaruh tersebut dapat dilihat dari besarnya nilai koefisien yang dihasilkan tiap variabel bebas.

Berikut adalah persamaan regresi yang dihasilkan dari analisis regresi linier.

$\mathrm{Y}=6.148+0.141 \mathrm{X}_{1}+0.230 \mathrm{X}_{2}+0.546 \mathrm{X}_{3}+$ e...........................(1)

Nilai konstanta sebesar 6.148 yang memiliki arti jika variabel X1,X2,dan X3 bernilai nol, maka efektivitas SAP berbasis akrual (Y) sebesar 6.148 satuan. Nilai B dari $\mathrm{X} 1$ yaitu 0.141 menunjukkan bahwa variabel kemampuan teknik personal (X1) mempunyai pengaruh positif pada efektivitas SAP berbasis akrual (Y) sebesar 0.141. Ini berarti apabila kualitas sumber daya manusia meningkat satu satuan, maka efektivitas SAP berbasis akrual sebesar 0.141 satuan. Nilai B dari X2 yaitu 0.230 menunjukan bahwa komitmen organisasi (X2) mempunyai pengaruh positif pada variabel $Y$ yaitu 0.230. Ini berarti apabila komitmen organisasi naik sebesar 1 satuan dengan anggapan bahwa variabel bebas lainnya konstan, maka efektivitas SAP berbasis akrual sebesar 0.230 satuan. Nilai $\mathrm{B}$ dari X3 yaitu 0.546 menunjukan bahwa variabel X3 berdampak positif pada variabel $Y$ yaitu 0.546 . Ini berarti apabila Y meningkat satu satuan admaka efektivitas SAP berbasis akrual sebesar 0.546 satuan.

Untuk mengetahui seberapa banyak variabel-variabel bebas yang digunakan dalam penelitian ini yaitu kualitas SDM (X1), 
Tabel 9.

Hasil Analisis Regresi Linier Berganda

\begin{tabular}{llrrrrr}
\hline \multirow{2}{*}{ Model } & \multicolumn{2}{c}{$\begin{array}{c}\text { Unstandardized } \\
\text { Coefficients }\end{array}$} & \multicolumn{2}{c}{$\begin{array}{c}\text { Standardized } \\
\text { Coefficients }\end{array}$} & & \\
\cline { 3 - 5 } & & $\mathrm{B}$ & Std. Error & Beta & & \multicolumn{1}{c}{ S } \\
\hline 1 & (Constant) & 6.148 & 2.624 & & 2.343 & 0.021 \\
& X1 & 0.141 & 0.065 & 0.173 & 2.171 & 0.032 \\
& X2 & 0.230 & 0.111 & 0.163 & 2.063 & 0.041 \\
& X3 & 0.546 & 0.112 & 0.388 & 4.858 & 0.000 \\
\hline
\end{tabular}

Adjusted $\mathrm{R}^{2} \quad 0,182$

F hitung $\quad 10,866$

Signifikansi F $\quad 0,000^{\mathrm{b}}$

a. Dependent Variable: Y

Sumber : Data diolah, 2018

komitmen organisasi (X2), dan pemanfaatan teknologi informasi (X3) dapat menjelaskan variabel terikat dalam penelitian ini yaitu efektivitas SAP berbasis akrual (Y). Hasil yang didapatkan setelah melakukan uji $\mathrm{R}^{2}$ yaitu bahwa $\mathrm{X} 1, \mathrm{X} 2$ dan $\mathrm{X} 3$ dapat menjelaskan variabel Y sebanyak 18 persen dan sisanya yaitu 82 persen dipengaruhi oleh faktor lainnya yang tidak digunakan dalam model penelitiaan ini. Setelah dilakukan pengujian $\mathrm{F}$ didapatkan hasil bahwa X1,X2, dan X3 berpengaruh serempak pada $\mathrm{Y}$. hal ini dapat dilihat dari nilai signifikansi dari $\mathrm{F}$ yaitu 0,000 yang kurang dari 0,05 . Dengan nilai signifikan yang lebih kecil dari 0,05 maka model yang digunakan dalam penelitian ini layak untuk diteliti.

Pengaruh kualitas SDM pada efektivitas SAP dengan basis akrual di SKPD Kabupaten Karangasem. Didapatkan bahwa $\beta 1$ yaitu 0,141 dengan nilai signifikan yaitu 0,032 yang merupakan lebih rendah dari 0,05 , maka $\mathrm{H} 1$ diterima dan $\mathrm{H} 0$ diterima yang berarti kualitas SDM memiliki pengaruh positif pada hasilnya pada efektivitas SAP dengan basis akrual.

Pengaruh komitmen organisasi pada efektivitas SAP berbasis akrual di SKPD Kabupaten Karangasem. $\beta 2$ bernilai yaitu 0,230 dengan signifikan 0,041 yang merupakan lebih rendah dari 0,05 . Artinya $\mathrm{H} 2$ diterima dan H0 ditolak. kesimpulannya komitmen organisasi berdampak atau memiliki pengaruh positif pada efektivitas SAP berbasis akrual.
Pengaruh pemanfaatan teknologi informasi pada efektivitas SAP berbasis akrual di SKPD Kabupaten Karangasem. $\beta 3$ bernilai yaitu 0,546 dengan signifikan 0,000 yang merupakan lebih rendah dari 0,05 . Artinya bahwa H3 diterima dan H0 ditolak. kesimpulannya pemanfaatan teknologi informasi berdampak atau memiliki pengaruh posistif pada efektivitas SAP berbasis akrual.

Pengaruh kualitas sumber daya manusia pada efektivitas SAP berbasis akrual di SKPD Kabupaten Karangasem. $\beta 1$ memiliki nilai 0,141 dan nilai signifikan 0,032 yang merupakan lebih rendah dari 0,05 . Berarti bahwa $\mathrm{H} 1$ diterima dan $\mathrm{H0}$ ditolak. Kesimpulannya kualitas sumber daya manusia berpengaruh positif pada efektivitas SAP berbasis akrual. Dengan meningkatnya kualitas SDM, maka efektivitas penerapan SAP dengan basis akrual juga akan meningkat.

Pemahaman dari SDM mengenai SAP berbasis akrual sangat diperlukan untuk mengindari terjadinya kesalahan-kesalahan dalam pembuatan laporan keuangan. Davis (2010) berpendapat bahwa SDM merupakan salah satu kunci keberhasilan penyusunan laporan keuangan. SDM tersebut harus memahamu betu mengenai SAP berbasis akrual. Sesuai dengan penelitian yang dilakukan oleh Ardiansyah (2012), yang menemukan adanya pengaruh positif antara kualitas SDM terhadap kesiapan penerapan standar akuntansi pemerintah berbasis akrual. Pengaruh komitmen organisasi pada 
efektivitas SAP berbasis akrual di SKPD Kabupaten Karangasem. Pada Tabel 9 dapat diketahuibahwanilaikoefisien $\beta 2$ sebesar 0,230 dengan nilai sig. $\mathrm{t}$ sebesar 0,041 yang lebih kecil dari 0,05 . Hal ini mengindikasi bahwa $\mathrm{H} 2$ diterima maka hasilnya menunjukkan bahwa komitmen organisasi berpengaruh positif pada efektivitas SAP berbasis akrual hal ini memiliki arti bahwa terdapat hubungan yang searah antara komitmen organisasi pada efektivitas SAP berbasis akrual. Jadi, dengan meningkatnya komitmen organisasi maka efektivitas SAP berbasis akrual di SKPD Kabupaten Karangasem juga akan terjadi peningkatan.

Sebuah kebiasaan yang telah dilakukan dalam jangka waktu yang panjang akan sangat sulit untuk diubah. Komitmen organisasi dalam membantu karyawannya dalam membiasakan diri mengenai perubahan pencatatan transaksi menjadi pencatatan transaksi berbasis akrual sangatlah diperlukan. Dukungan berupa komitmen tersebuta akan membantu penerapan SAP berbasis akrual yang lebih efisien. Davis (2010) berpendapat bahwa komitmen menjadi dasar dari keberhasilan penerapan SAP berbasis akrual. Dengan demikian, anggota organisasi harus memiliki komitmen yang sama dan saling memberi dukungan pada organisasi yang memiliki tanggungjawab yaitu menerapkan SAP dengan basis akrual. Adventana (2013) menemukan bahwa komitmen organinsasi memiliki pengaruh yang positif pada penerapan standar akuntansi pemerintah berbasis akrual.

Pengaruh pemanfaatan teknologi informasi pada efektivitas SAP berbasis akrual di SKPD Kabupaten Karangasem. $\beta 3$ yaitu 0,546 memiliki nilai signifikan yaitu 0,000 yang merupakan lebih rendah 0,05 berarti $\mathrm{H} 3$ diterima dah $\mathrm{H} 0$ ditolak. kesimpulannya pemanfaatan teknologi informasi berpengaruh posistif pada efektivitas SAP berbasis akrual. Dengan meningkatnya pemanfaatan teknilogi informasi akan berdampak pada peningkatan pada efektivitas SAP berbasis akrual di SKPD Kabupaten Karangasem.

SAP berbasis akrual pada kenyataannya memang lebih rumit jika dibandingkan dengan SAP berbasis kas. Hal ini disebabkan karena Standar Akuntansi Pemerintah berbasis akrual mencatat seluruh transaksi baik kas maupun non kas dan mencatat estimasi dampak dari transaksi sekarang dan perubahan kebijakan. Maka dari itu, diperlukan bantuan dari teknologi informasi yang memadai untuk membantu karyawan dalam penerapan SAP berbasis akrual. Dengan kesiapan dari sistem informasi maka penerapan SAP berbasis akrual dapat berjalan secara efektif dan efisien (Widjajanto, 2001).Sesuai dengan penelitian sebelumnya yang dilakukan oleh Apriliani (2015), yang menyatakan bahwa teknologi informasi memiliki pengaruh yang positif pada implementasi standar akuntansi pemerintahan berbasis akrual, dan Tikk (2010) berdasarkan penelitian yang dilakukannya menyatakan bahwa perubahan dari SAP berbasis kas ke SAP berbasis akrual memerlukan dukungan dari sistem teknologi informasi yang memadai.

\section{SIMPULAN}

Hasil yang didapatkan setelah melakukan pengujian hipotesis adalah kualitas SDM berdampak atau berpengaruh positif pada efektivitas penerapan SAP dengan basis akrual di Kabupaten Karangasem, komitmen organisasi berdampak atau berpengaruh yang positif pada pada efektivitas penerapan SAP dengan basis akrual di Kabupaten Karangasem, dan penerapan teknologi informasi berdampak atau berpengaruh yang positif pada efektivitas penerapan SAP dengan basis akrual di Kabupaten Karangasem.

\section{REFRENSI}

Adriana. (2008). Cash Versus Accrual Accounting In Public. Journal University Babes Bolyai.

Adventana, G. A. (2013). Analisis Faktorfaktor yang mempengaruhi Pemerintah Provinsi DIY dalam Implementasi SAP Berbasis Akrual Menurut PP No71 Tahun 2010. Fakultas Ekonomi Universitas Atma Jaya Yogyakarta. 
Anthony, R., \& Govindrajan, V. (2007) Management Control System. New york.

Apriliani, D. (2015). Analisis Faktor-faktor Yang Mempengaruhi Kesuksesan Implementasi Standar Akuntansi Pemerintah Berbasis Akrual Pada Peerintah Kabupaten Jepara. Program Studi Akuntasi Fakultas Ekonomi Universitas Muria Kudus.

Ardiansyah. (2012). Faktor-faktor yang Mempengaruhi Kesiapan Pemerintah Daerah Dalam Penerapan PP No. 71 Tahun 2010.

Davis, N. (2010). Accrual Accounting and the Australian Public sector-A Legitimation Explanation. Australasian Accounting Business and Finance Journal, 4(2), 61-78.

Ghozali, I. (2016). Aplikasi Analisis Multivariete Dengan Program IBM SPSS 23. semarang: Badan penerbit Universitas Diponergoro.

Hamzah, A. (2009). Evaluasi Kesesuaian Model Keperilakuan dalam Penggunaan Teknologi Informasi di Indonesia. yogyakarta.

Husein, U. (2004). Riset Pemasaran Dan Perilaku Konsumen. jakarta: PT. Gramedia Pustaka.

Luthans, F. (2006). Perilaku Organisasi (10th ed.).
Ritonga, A. (2010). Ini Dia Alasan Masyrakat Tolak Bayar Pajak.

Simanjuntak. (2005). Manajemen Dan Evaluasi Kinerja. Jakarta: fakultas Ekonomi Universitas Indonesia.

Stefanescu, A. (2011). Accrual Accounting, Foundation For The Financial Reporting Into The Public Sector Entities. Journal Annales Universitatis Apulensis Series Oeconomica.

Sugiyono. (2018). Metode Penelitian Kuantitatif, kualitatif, dan R\&D.

Tikk, J. (2010). Accounting Changes In The Public Sector In Estonia. Business: Thoery and Practice Research Journal, 11(1).

Widjajanto, N. (2001). Sistem Informasi Akuntansi. Jakarta: erlangga.

Widyastuti. (2015). Analisis Kesiapan Pemerintah Daerah Dalam Menerapkan Standar Akuntansi Pemerintah Berbasis Akrual Di Kabupaten Gianyar. E-Journal S1 Ak Universitas Penddikan Ganesha Jurusan Akuntansi Program S1.

Zangaro, G. A. (2007). Organizational Commitment: A Concept Analysis. 